\title{
A single functional testis and long deferent duct papillae: the peculiar male reproductive tract of the classically polyandrous, sex-role reversed Black Coucal (Centropus grillii)
}

\author{
Roland Frey • Wolfgang Goymann
}

Received: 10 November 2008/Revised: 20 March 2009/Accepted: 23 March 2009/Published online: 18 April 2009

(C) The Author(s) 2009. This article is published with open access at Springerlink.com

\begin{abstract}
In many birds, the male reproductive tract is asymmetric with the left testis being larger than the right one. Coucals (Centropodidae) represent an exception as the asymmetry is typically reversed. Here, we describe the functional morphology of the reproductive tract of the African Black Coucal (Centropus grillii), a bird species with reversed sex-roles and a classical polyandrous mating system. In this species, the left testis has been reduced to a tiny, disk-like vestige that in almost all cases examined was not visible macroscopically. The vestigial left testis apparently does not participate in sperm production but has retained a vestigial left excurrent duct system. By contrast, the right deferent duct was engorged with sperm, suggesting a sperm storage function. Both deferent ducts opened on the tip of spectacularly long, erectile deferent duct papillae into the urodaeum of the male cloaca. Behavioural observations suggest that they may function as "pseudophalli". Testis mass represented $0.49 \%$ of body mass, less than half the size of other classical polyandrous bird species. Assuming moderate to high levels of sperm competition this represents a paradox. Heavy demands on
\end{abstract}

Communicated by F. Bairlein.

\section{R. Frey}

Research Group 5: Reproduction Management,

Leibniz Institute for Zoo and Wildlife Research (IZW),

Alfred-Kowalke-Strasse 17, 10315 Berlin, Germany

e-mail: frey@izw-berlin.de

\section{W. Goymann ( $\square)$}

Evolutionary and Environmental Physiology Lab,

Abteilung für Verhaltensneurobiologie,

Max-Planck-Institut für Ornithologie,

Eberhard-Gwinner-Straße Haus 6a,

82319 Seewiesen, Germany

e-mail: goymann@orn.mpg.de the energy budget while caring for altricial young may have prevented males from maintaining two testes and large bilateral sperm storage devices. Reduced testis mass may be compensated for by frequent transfer of small amounts of sperm. Female Black Coucals have not evolved any corresponding cloacal specializations, but like all other birds have sperm storage tubules.

Keywords Male genital system - Testis asymmetry Female genital system $\cdot$ Sperm storage tubules . Comparative anatomy

\section{Introduction}

In many bird species, the testes are asymmetric, with the left testis usually being larger than the right one (Lake 1981). In a few bird taxa including the coucals (Centropodinae, genus Centropus), this pattern is reversed and the right testis is larger than the left (e.g. Centropus monachus, C. senegalensis and C. t. toulou; Rand 1933). Some coucals seem to have driven this asymmetry to the extreme, as they lack a left testis at all (C. medius and C. affinis; Bernstein 1860). In contrast, the White-browed Coucal (C. superciliosus) conforms to the more typical avian pattern, with the left testis being larger than the right one (Friedmann 1927; Rand 1933).

The extreme asymmetry of the testes in many coucals is associated with a social system in which the males take the larger share of parental duties. This bias in parental care is most pronounced in the African Black Coucal (C. grillii). This bird expresses a rare mating system termed classical polyandry. Females of this species are the more competitive sex, they are much larger than males and they sing to defend large territories and attract mates. Each female lays 
sequential clutches for up to four males, each of which attends his own nest within the territory of the female. In contrast, males rarely vocalize, do not defend territories, but incubate the eggs and feed the young. Females contribute little or nothing to parental care (Vernon 1971; Goymann et al. 2004a, 2005). In Black Coucals, the testicular asymmetry has been reported to be extremely developed, with the left testis being greatly reduced or absent (Ligon 1997), but detailed investigations have so far been lacking.

The aim of this study was to describe the functional morphology of the reproductive tract of African Black Coucals and relate it to the peculiar natural history of this species.

\section{Methods}

We dissected the reproductive tract of six adult male and one adult female Black Coucals, caught during the early breeding seasons in 2004 and 2005, about 1-2 weeks before we found the first nests. For some external measurements, we included additional data from birds caught between 2001 and 2006. All specimens were caught using mist nets in the Usangu wetlands, located at $8^{\circ} 41^{\prime} \mathrm{S}, 34^{\circ} 5^{\prime} \mathrm{E}$ in the Mbeya region, Tanzania. After measurement, the six males and one female were killed by decapitation and preserved immediately in 3\% formalin solution. Macroscopic dissection was carried out on the specimens submersed in water. Consecutive dissection steps were recorded by digital photography (Nikon D70s; Nikon, Tokyo, Japan) and analysed in Adobe Photoshop v.5.5 (Adobe Systems, San José, CA, USA). We measured testis size with callipers and applied the standard nomenclature (NAA 1993) to describe the anatomical structures. Testis volume was calculated using the formula for an oval body: volume $\left(\mathrm{mm}^{3}\right)=4 / 3 \pi \times a^{2}\left(\mathrm{~mm}^{2}\right) \times b(\mathrm{~mm})$, with $a=1 / 2$ width of the testis, $b=1 / 2$ length of the testis in $\mathrm{mm}$. Testis mass was determined from wet weight of previously frozen tissue $(n=3)$ or from formalin preserved tissue $(n=5)$. Calhim and Birkhead (2007) showed that formalinfixed testes do not change in mass, hence these two different measures are comparable. All measures are given using the mean \pm standard deviation. Testis measurements were available for two additional individuals caught during the breeding season in 2002 and not subjected to detailed dissection.

Histological sections of the region of origin of the left deferent duct, including the left adrenal, were made according to routine procedures and staining with HE (hematoxylineosin), Van Gieson, PAS (periodic acid Schiff) and Azan. Right and left deferent duct papillae were sectioned longitudinally and stained with HE and Azan to potentially detect their intrinsic smooth musculature.
Microphotographs of the histological sections were taken with a universal microscope Axioplan (Carl Zeiss, Oberkochen, Germany) connected to a digital unit ai4 DIG 3300 (Olympus, Hamburg, Germany). Microphotographs were processed on a personal computer using cell ${ }^{\mathrm{IP}}$ Soft imaging system (Olympus).

\section{Results}

Males

\section{Extreme testis asymmetry}

Macroscopically, the left testis and epididymis were not visible in all individuals (Fig. 1), except one which had a small left testis, about $4 \mathrm{~mm}$ in length and $1.5 \mathrm{~mm}$ in width (Fig. 2a). The right testis was of globular to ovoid shape. In the latter case, the blunt pole was directed cranially. The volume of the right testis was $468.8 \pm 155.6 \mathrm{~mm}^{3}$ (mean $\pm \mathrm{SD}$ ) with a testis mass of $0.45 \pm 0.14 \mathrm{~g}(n=8)$.

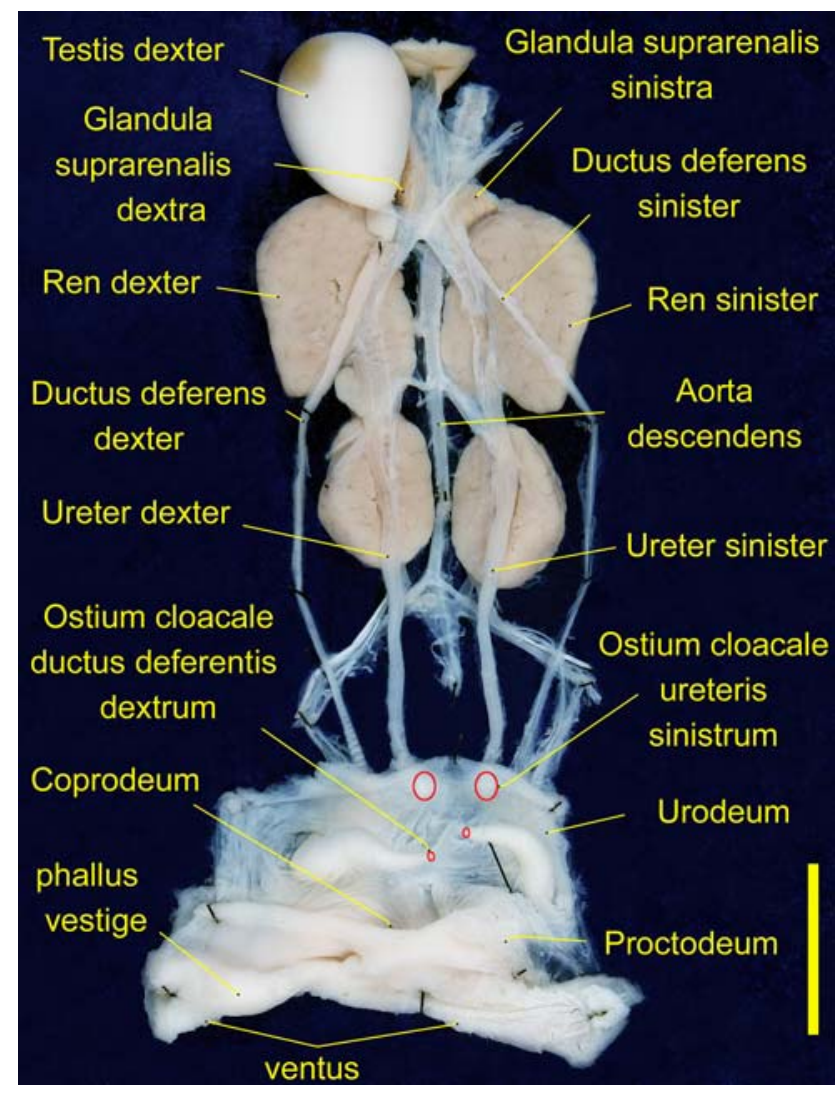

Fig. 1 Excised and pinned urogenital tract of an adult male Black Coucal (Centropus grillii). Cloaca opened left laterally and spread. Left testis macroscopically not visible. Deferent ducts traverse the dorsal cloacal wall lateral to the ureters and their respective cloacal openings are located on the tips of large papillae. Ventral view. Scale bar $10 \mathrm{~mm}$ 

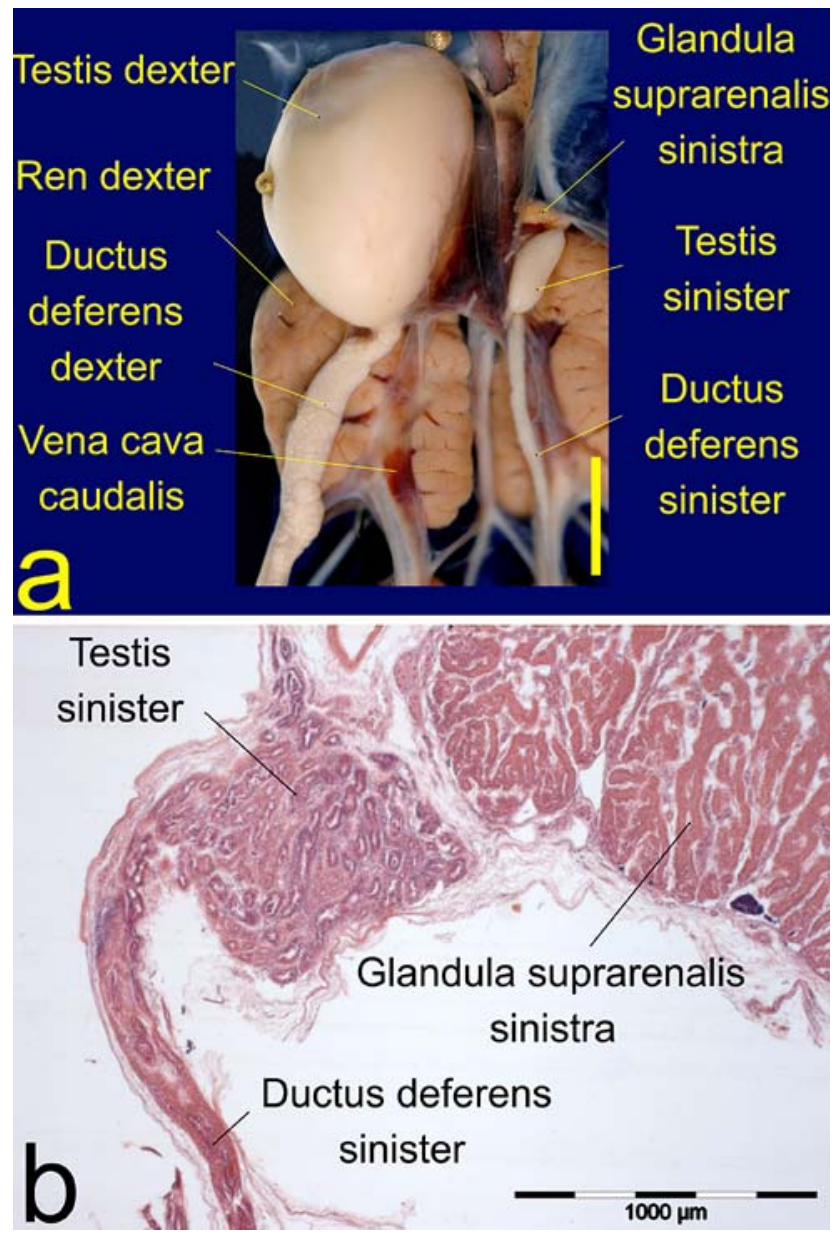

Fig. 2 Left testis vestige in an adult male Black Coucal. a Macroscopically visible in one individual. Note different diameters of right and left deferent ducts. Ventral view. Scale bar $5 \mathrm{~mm}$. b Only microscopically visible in all other individuals. Disc-like left microscopic testis vestige always attached to the left suprarenal gland

This corresponds to $0.49 \pm 0.14 \%$ of the total body mass of the male Black Coucals measured (Table 1). The right epididymis was situated dorsomedially.

Microscopically, a tiny disc-like vestige of the left testis could be substantiated in all individuals (Fig. 2b). It was tightly connected to the left adrenal and contained few seminal tubules and interstitial Leydig cells. The seminal tubules appeared to contain Sertoli cells but no spermatogonia, except in the one individual with macroscopically visible left testis (see above) where all stages of spermiogenesis but only very few spermatozoa could be detected within the seminal tubules. The excurrent duct system of the left testis was also vestigial; rete testis, efferent ductules, and connecting ductules could not be clearly differentiated, but there existed a tube that emerged from the left testis vestige and connected to the left deferent duct.

\section{Testis position}

The right testis was suspended from the dorsal body wall by a short connective tissue fold, the right mesorchium. A left mesorchium was lacking. The cranial extremity of the right testis lay ventrally adjacent to the caudal end of the right lung. The caudal third to caudal half of the right testis covered the cranial portion of the right kidney ventrally. The right epididymis lay adjacent to the dorsomedial aspect of the testis. The medial aspect of the right testis touched the caudal vena cava and the aorta. According to the one individual with macroscopically visible left testis and to the microscopical sections, the left testis vestige took up a corresponding position near the large blood vessels and laterally to the left adrenal. The left adrenal was situated between the caudal vena cava and the cranial pole of the cranial portion of the left kidney. The right adrenal was somewhat more cranially, between the caudal vena cava and the medial aspect of the right testis (Fig. 2a).

\section{Right and left deferent duct}

Both deferent ducts were fully expressed, at least regarding their respective apparent length from the cranial portion of the kidney up to the cloaca. Macroscopically, the left deferent duct in all individuals originated cranially near the ipsilateral adrenal at the same level where, on the contralateral side, the transition of the epididymis into the deferent duct was located and where the right deferent duct
Table 1 Measurements and calculations of the single functional right testis in Black Coucals (Centropus grillii)

a Referring to wet mass, other masses refer to formalin-fixed testes

\begin{tabular}{lccllll}
\hline ID & $\begin{array}{l}\text { Length } \\
(\mathrm{mm})\end{array}$ & $\begin{array}{l}\text { Width } \\
(\mathrm{mm})\end{array}$ & $\begin{array}{l}\text { Volume } \\
\left(\mathrm{mm}^{3}\right)\end{array}$ & $\begin{array}{l}\text { Mass } \\
(\mathrm{g})\end{array}$ & $\begin{array}{l}\text { Body } \\
\text { mass }(\mathrm{g})\end{array}$ & $\begin{array}{l}\text { Testis/body } \\
(\%)\end{array}$ \\
\hline M 01 & 13.40 & 10.40 & 758.9 & $0.63^{\mathrm{a}}$ & 102 & 0.62 \\
M 04 & 12.60 & 9.30 & 570.6 & $0.64^{\mathrm{a}}$ & 90 & 0.71 \\
M 07 & 9.70 & 7.35 & 274.4 & 0.27 & 94 & 0.29 \\
M 08 & 10.50 & 8.45 & 392.5 & 0.38 & 90 & 0.42 \\
M 09 & 11.20 & 8.40 & 413.8 & 0.40 & 78 & 0.51 \\
M 10 & 10.85 & 7.45 & 315.3 & 0.32 & 94 & 0.34 \\
M 14 & 11.80 & 9.30 & 534.4 & $0.47^{\mathrm{a}}$ & 91 & 0.52 \\
M 25 & 12.15 & 8.78 & 490.4 & 0.51 & 98 & 0.52 \\
\hline
\end{tabular}


detached from the testicular capsule towards the cloaca (Fig. 1). Microscopically, the left deferent duct, via the vestigial excurrent duct system, was connected to the left testis vestige (Fig. $2 b$ ).

In the transitional area between the right epididymis and the right deferent duct, the excurrent duct system was undulating and capacious. The course of both right and left deferent ducts was lateral to the respective ureters (Fig. 1). The distance between the caudal pole of the right testis and entry of the right deferent duct into the cloacal wall was $34.4 \pm 1.6 \mathrm{~mm}(n=5)$.

The right deferent duct appeared turgid and engorged with sperm that could be seen as a whitish opaque mass inside the undulatory and pronouncedly meandering looped duct covered by a connective tissue sheath. In contrast, translucency of the left connective tissue sheath and deferent duct indicated that it did not contain sperm. In its cranial third, the diameter of the right deferent duct was about three times that of the left, also indicative of an engorgement of sperm in the right and a lack of sperm in the left deferent duct (Fig. 1). Neither of the deferent ducts formed a seminal glomus, i.e. a ball of tightly packed deferent duct coils. Accessory male genital glands were lacking.

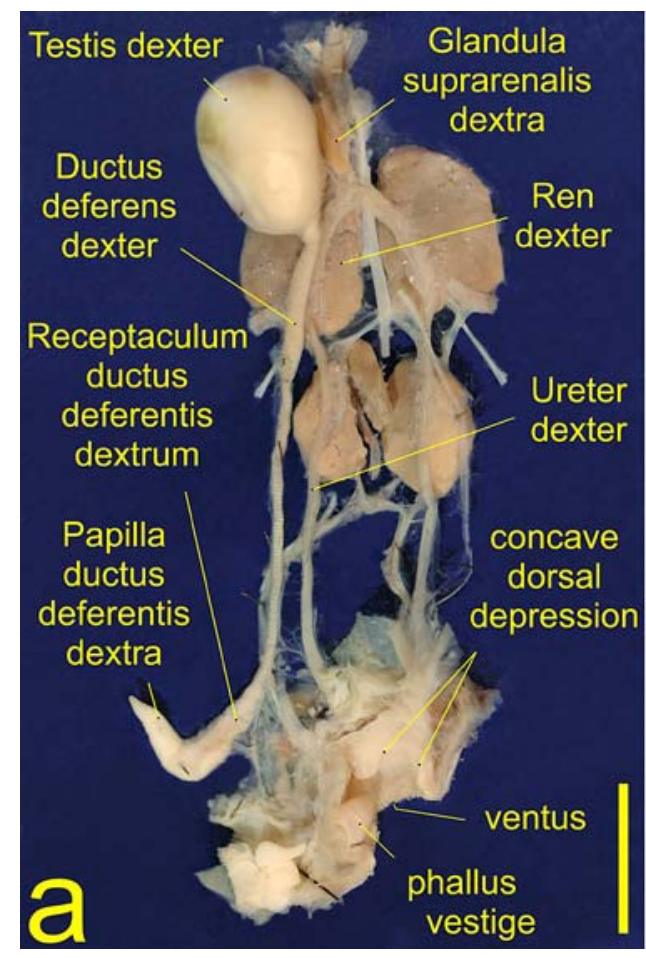

Fig. 3 Relative length of right deferent duct papilla in an adult male Black Coucal. a Overview with right testis, deferent duct, receptacle and deferent duct papilla. Right deferent duct papilla excised from cloacal wall and pinned laterally. The total length of the deferent duct papillae comprises about $20 \%$ of the distance between the caudal pole of the testis and the entry of the deferent duct into the cloacal wall. In

\section{Deferent duct papillae}

After taking their typical course laterally along right and left ureter, both deferent ducts traversed the dorsal cloacal wall. In this region, the convoluted right deferent duct increased somewhat in diameter and became spindleshaped, thus forming a slender receptacle (Fig. 3). Large amounts of sperm in the right deferent duct receptacle could be confirmed histologically (Fig. 5). Owing to the lack of whitish opaque sperm contents, the exact shape could not be accurately observed macroscopically in the left deferent duct. But the connective tissue sheath of the left deferent duct also seemed to increase in diameter towards the cloacal wall.

Both deferent ducts opened on the tip of conspicuously long, slender conical deferent duct papillae into the urodaeum of the cloaca. The length of the right deferent duct papilla was $8.0 \pm 3.3 \mathrm{~mm}$ and the left one was $6.7 \pm 2.0 \mathrm{~mm}(n=5)$. The longitudinal axes of these papillae were adjusted in a transverse plane.

The thicker ends (bases) of the papillae were situated laterally, where the deferent ducts pierced the cloacal wall, whereas their tips pointed to the contralateral side (Figs. 1, 4). Inside the right papilla, the terminal portion of

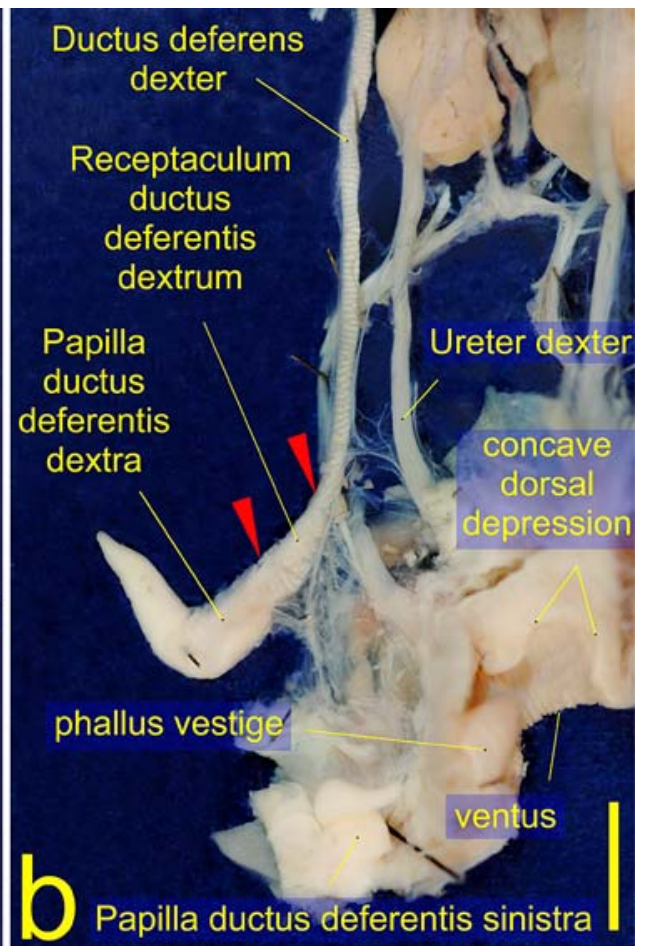

the ancestral situation, papilla length is $<5 \%$ of that distance. Ventral view. Scale bar $10 \mathrm{~mm}$. b Detail of same image with close-up view of terminal portion of right deferent duct, its receptacle (between two red arrows) and papilla. Note concave depression of dorsal lip of ventus for accommodation of the phallus vestige in its resting position. Medial view of receptacle and papilla. Scale bar $5 \mathrm{~mm}$ 
Fig. 4 Position of an adult male Black Coucal's deferent duct papillae inside the urodeum. a In situ, b excised. Note position of cloacal openings of ureters (red ellipses). Ventral view. Scale bar $5 \mathrm{~mm}$, respectively

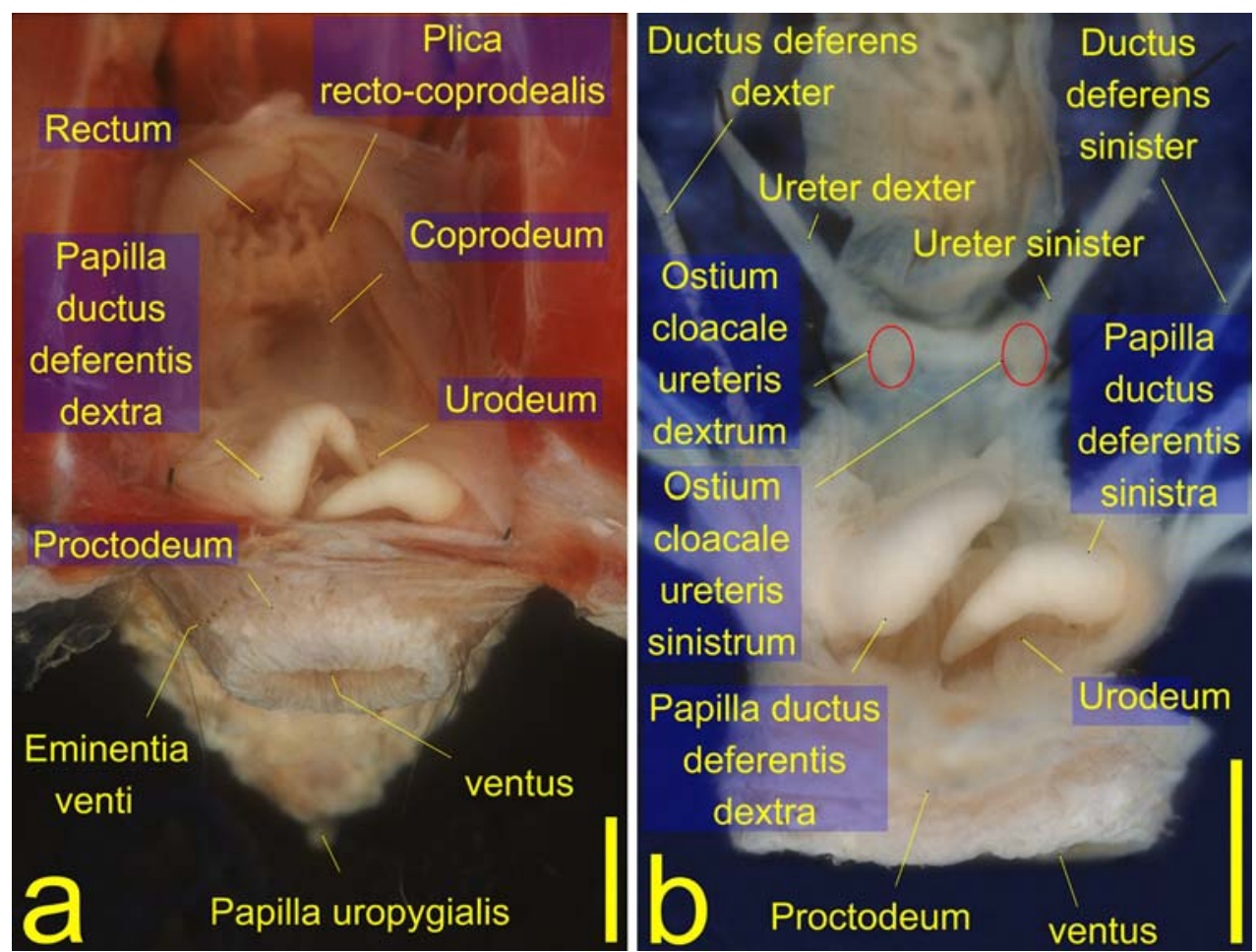

Females

\section{Genital organs}

The female genital organs corresponded to the typical situation in birds. Only the left ovary appeared macroscopically. It contained several follicles of different sizes and calices (postovulatory follicles). The oviducts were strongly asymmetric: the left one was long, large and fully functional whereas the right oviduct was very short and vestigial. It was attached to the right cloacal wall lateral to the opening of the rectum into the coprodeum (Fig. 7).

The left oviduct consisted of the same portions as those found in other birds, namely infundibulum, magnum, isthmus, uterus (shell gland) and vagina, in craniocaudal direction. In our individual, the uterus was distended by an egg on its passage from the ovary to the cloaca.

\section{Sperm storage tubules}

A number of sperm storage tubules (fossulae spermaticae) connected to the S-shaped cranial vagina-portion of the left oviduct near the uterovaginal junction. These were elongated narrow tubules which diverged from the wide, longitudinally-folded lumen of the vagina. In cross-section, the sperm storage tubules were lined by tall columnar cells with basal nuclei and apical microvilli. Total diameter of the fossulae was about $50 \mu \mathrm{m}$, luminal diameter about $15 \mu \mathrm{m}$. The sperm storage tubules contained large numbers 


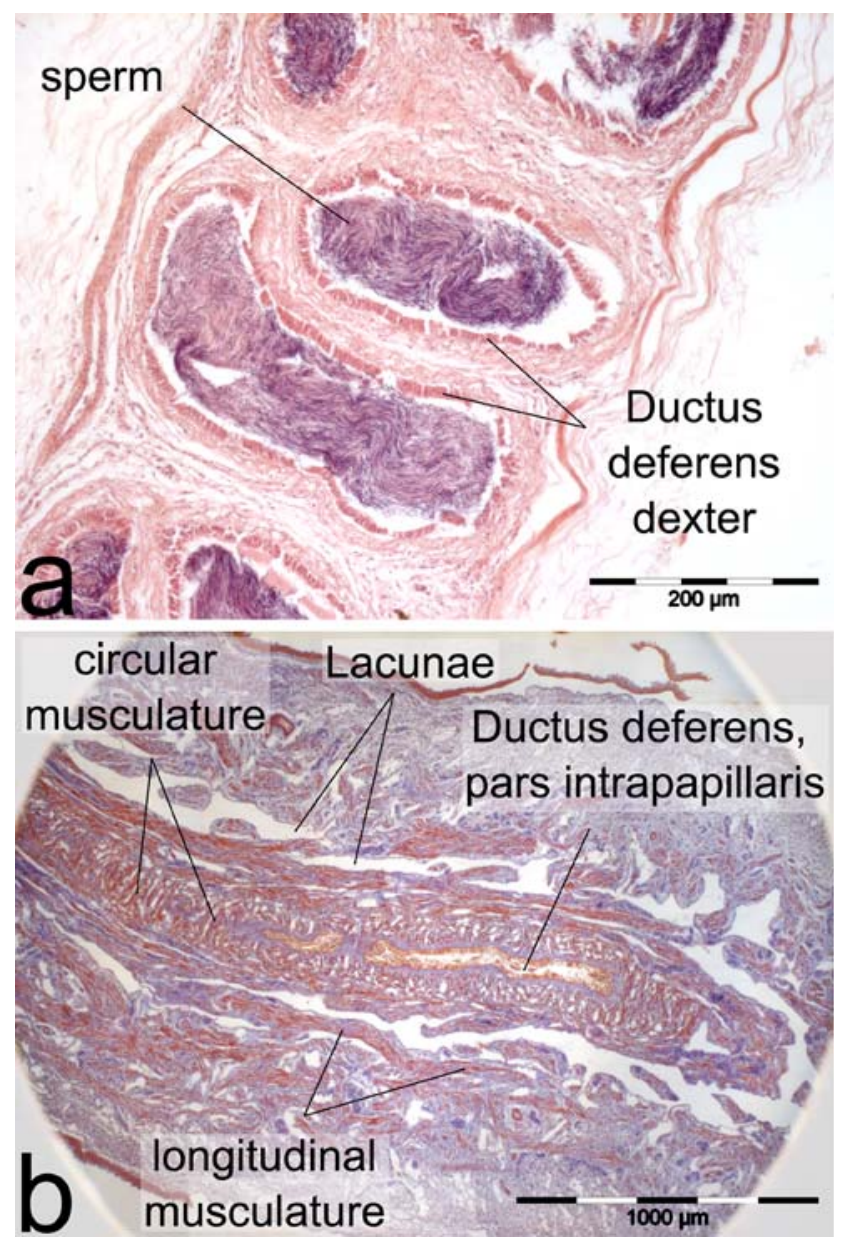

Fig. 5 Longitudinal sections of right deferent duct receptacle and deferent duct papilla in an adult male Black Coucal. a Individual coils of the deferent duct receptacle contain large amounts of sperm. $\mathbf{b}$ The central intrapapillary part of the deferent duct is surrounded by a circular muscle layer, a longitudinal muscle layer and an interspersed system of lacunae

of spermatozoa. Their heads were oriented towards the blind end of the tubule and their tails parallel to its long axis (Fig. 8).

\section{Cloaca}

The structure of the female cloaca corresponded to the typical plan of birds (Gilbert 1979). In craniocaudal direction, it consisted of coprodeum, urodeum and proctodeum. Right and left ureter drained into the urodeum, about $4 \mathrm{~mm}$ apart, by simple openings, i.e. without the formation of any papillae (Fig. 9). Lateral to the left ureter, the functional left oviduct connected to the urodeum by a slit-like opening. The cloacal bursa opened dorsally into the proctodeum (Fig. 9). Inconspicuous dorsal and ventral lips demarcated the proctodeum against the ventus, the outward opening of the cloaca. The elevation of the female cloaca relative to the surrounding

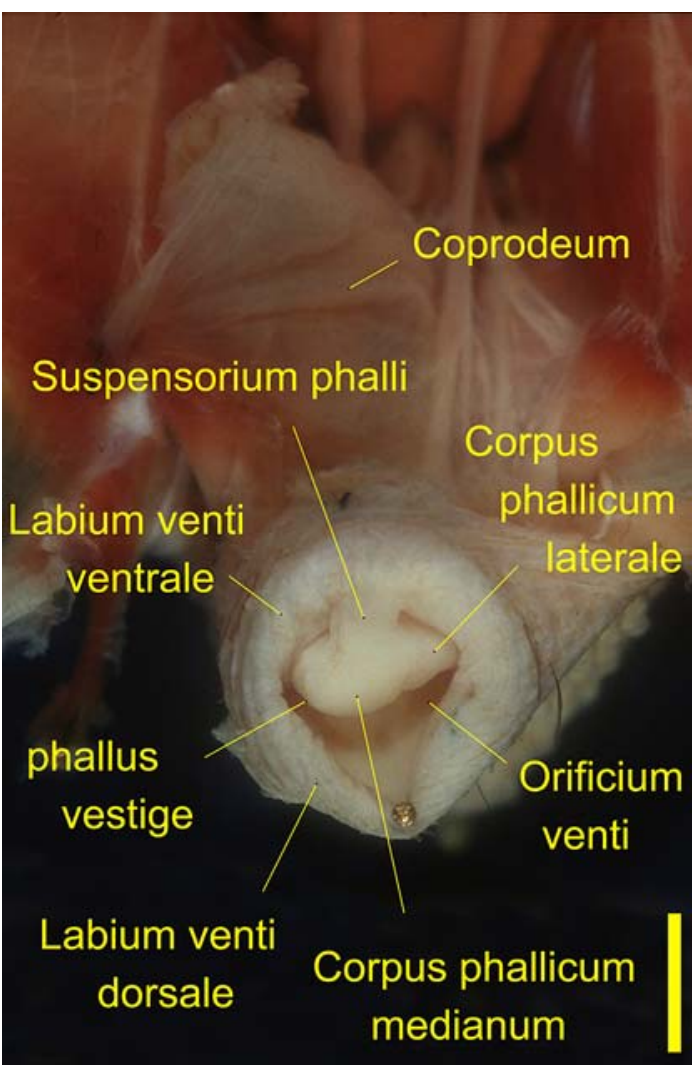

Fig. 6 Phallus vestige in an adult male Black Coucal. As in the domestic rooster it consists of an unpaired median phallic body and paired lateral phallic bodies each flanked by lymphatic folds (not visible here). The phallus vestige is sutured to the ventral lip of the ventus by a narrow connective tissue ridge. Top view, dorsal lip of ventus pulled caudally. Scale bar $5 \mathrm{~mm}$

pubic region was $3.1 \pm 1.2 \mathrm{~mm}$ and its width at the basis was $10.4 \pm 1.7 \mathrm{~mm}(n=120)$.

\section{Discussion}

Testis position

The position of the single, macroscopically visible large right testis of Black Coucals did not substantially differ from that in birds with two testes (cf. Benoit 1950; Lofts and Murton 1973; Lake 1981; Waibl and Sinowatz 1999). The position of the microscopically, only in one individual macroscopically visible, vestigial left testis also corresponded in topographical relationships with that of typically-sized left testes in other bird species.

\section{Testis reduction}

The testis has two basic functions: the endocrine production of male sexual hormones and the formation and 


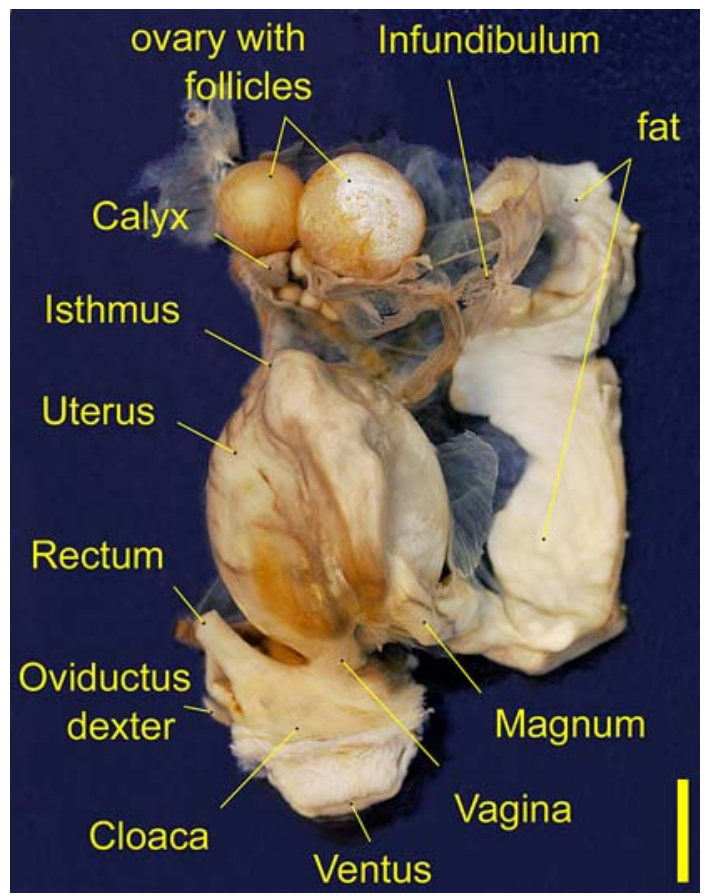

Fig. 7 Genital organs of an adult female Black Coucal. Excised and pulled apart to show individual parts. Uterus distended by an egg on its passage to the cloaca. Ventral view. Scale bar $10 \mathrm{~mm}$

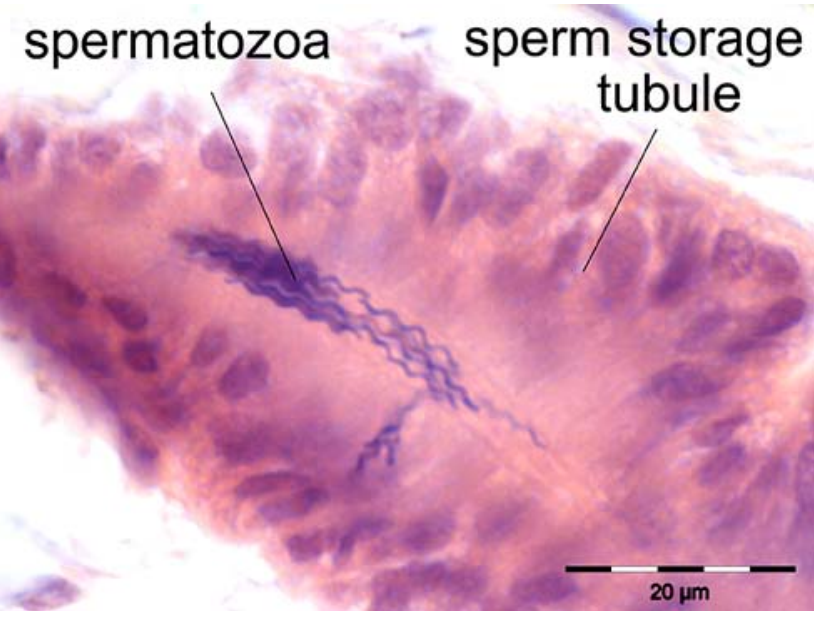

Fig. 8 Transverse section of a sperm storage tubule (fossula spermatica) of an adult female Black Coucal during the breeding season. Numerous spermatozoa are stored in its narrow lumen for subsequent fertilisations

secretion of spermatozoa (Lake 1957). Reduction to a microscopical vestige suggests that endocrine and secretory functions of the left testis of Black Coucals are negligible.

It had been argued that the almost complete evolutionary reduction of one testis could be a mechanism to reduce androgen levels in males thus promoting sex-role reversed behaviours (Ligon 1997), because high levels of androgens are known to interfere with parental care (Wingfield et al.

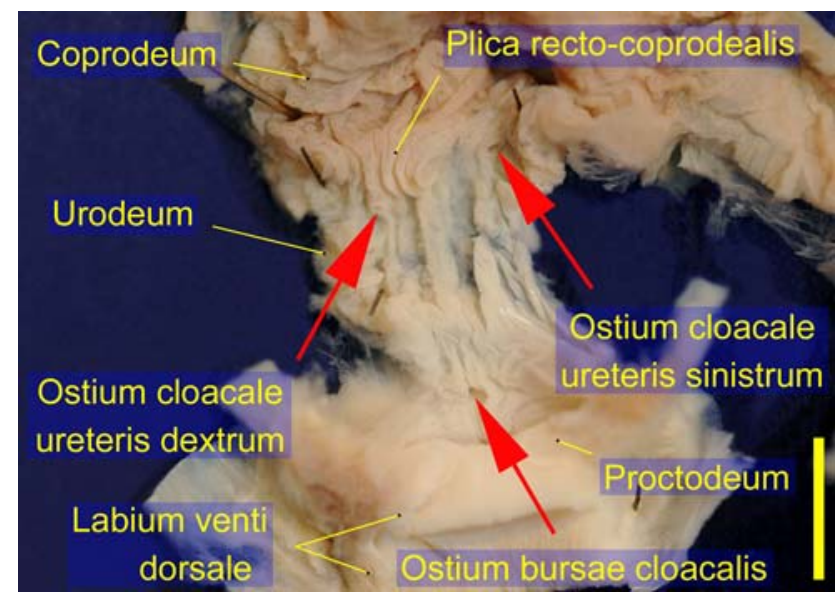

Fig. 9 Dorsal cloacal wall of adult female Black Coucal. Openings of ureters and cloacal bursa (red arrows). In contrast to males, female Black Coucals do not have any macroscopically visible cloacal specializations. Ventral view. Scale bar $5 \mathrm{~mm}$

1990). However, this idea has been recently rejected. Circulating levels of testosterone and other androgens in male Black Coucals are similar to socially monogamous male birds with two testes and indeed much higher than expected in a tropical bird (Goymann et al. 2004b; Goymann and Wingfield 2004; Voigt and Goymann 2007).

Both intraspecific and interspecific variation in avian testis size are positively related to parameters such as the number of testicular sperm (Lake 1971; Lofts and Murton 1973), the number of sperm per ejaculate (Parker et al. 1942), ejaculate volume and sperm concentration (Møller 1988 , 1991). In view of the almost completely reduced left testis and its few testicular tubules devoid of spermatogonia, we may reasonably conclude that the number of testicular sperm and the number of sperm per ejaculate have been reduced to about one half of that of a hypothetical ancestor still possessing two testes.

There is evidence that increased sperm competition leads to large relative testis size and accordingly large relative sperm production rates (Møller 1991). The testis mass of adult Black Coucals during the breeding season is $0.49 \%$ of the total body mass, i.e. less than half the size of other classically polyandrous bird species which range between 1 and 2\% of body mass (Møller 1991). Is this low proportion of the testis mass indicative of a low level of sperm competition in Black Coucals? Male Black Coucals guard their mates before egg laying. However, once the first egg is laid, males start to incubate and can no longer effectively guard the female (Goymann et al. 2004a). As a consequence, "extra-pair" fertilisations are quite common with about $37 \%$ of nests containing at least one extra-pair young (Muck et al., in press). Hence, by eliminating one testis, Black Coucals may have reduced their total testes mass despite moderate to high levels of sperm competition. 
Given that there is strong interspecific evidence that sperm competition leads to the evolution of large relative testes (Møller 1991; Calhim and Birkhead 2007), this is a paradox.

On the other hand, sperm competition does not explain all of the variance in testis size and there are also costs associated with maintaining large testes (Briskie and Montgomerie 2007). Typically, intense sperm competition correlates with low levels of male parental care. Thus, such males typically heavily invest in attracting mates and producing large amounts of sperm. In contrast, Black Coucal males mainly invest in parental care (Andersson 1995; Goymann et al. 2005). Thus, they may be caught in a trade-off between sperm production and parental care. Recently, Kokko and Jennions (2008) pointed out that there is no a priori reason to assume that males should automatically put more emphasis on pre-mating investment (such as sperm production to maximise fertilisation success) than on post-mating investment (such as parental care). This is speculative, but male Black Coucals (and more generally, all coucals with only one functional testis) may more heavily invest in paternal care instead of sperm production, which may have led to the retention of only one functional testis.

\section{Deferent ducts}

As observed in the domestic fowl (Gallus gallus; Nishiyama 1951) and in the domestic turkey (Meleagris gallopavo; Lake 1957), the greatly expanded lumen of the cranial third of the right deferent duct of the male Black Coucal also appears to function as the main sperm storage place (Fig. 2). This is in contrast to most passerine birds, e.g. the Oregon Junco (Junco hyemalis oreganus; Bailey 1953), and the House Sparrow (Passer domesticus; Witschi 1935; Lake 1981; Aire 2007), which possess a large sperm reservoire, the seminal glomus, close to the caudal end of the deferent duct. Judging from its extensive loops, the length of the right deferent duct in Black Coucals considerably exceeds that of the straight distance between the caudal pole of the testis and the entry into the cloacal wall-just as in other male birds. In the domestic fowl, the actual length of the deferent duct, as a result of its meandering course, exceeds the apparent length six-fold (Lake 1981). Accordingly, we may reasonably assume a similar ratio in male Black Coucals resulting in an average actual right deferent duct length of around $200 \mathrm{~mm}$.

The actual shape of the left deferent duct could not be clearly identified. It appeared, however, that it lacked any major loops and took an almost straight course from its origin near the left adrenal to the cloaca, thus resembling the inactive deferent duct of many birds during the nonbreeding period (cf. Bailey 1953; Lofts and Murton 1973;
Lake 1981). The cranial end of the left deferent duct was still connected to the ipsilateral, although vestigial, testis. The microscopically detectable connecting tubule between the left testis vestige and the left deferent duct can be reasonably assumed to be a homologue of the left epididymis.

The histological sections provided no evidence of sperm production by the vestigial left testis, except in the single individual with a macroscopically visible left testis where a negligible amount of spermatogenesis seemed to occur. Retaining the left deferent duct might result from constraints during embryonic development.

\section{Deferent duct papillae}

Only few birds possess a truly intromittent phallus (ratites, tinamous, anseriforms, cracids). In the large majority of birds, the phallus is small and non-intromittent (King 1981). Although being non-intromittent, this phallus can be erected to some extent during copulation by a lymphatic mechanism (Liebe 1914; Nishiyama 1950, 1955). Basically, it serves to guide the semen, discharged into its median groove by the papillae of the deferent duct, into the female cloaca. Presumably, this is assisted to some degree by the eversion of both male and female cloacae during copulation (involving the strong circum-cloacal musculature). In Black Coucals, as in other avian species, males appear to have a greater share in establishing close contact of male and female cloaca, as their cloacal opening, the ventus, is elevated to a higher degree against the surrounding pubic region than that of females (see "Results", and Goymann et al. 2004a). This more pronounced eminence of the male cloaca may facilitate contact during copulation.

Relative to other species of birds, the size of the deferent duct papillae in $C$. grillii (average length of the right papilla $=8.0 \mathrm{~mm}$ ) is enormous. In the domestic fowl, with a body mass several times that of the Black Coucal, the deferent duct papillae are short wart-like structures, 1-2 mm in length (Lake 1981; Waibl and Sinowatz 1999). A comparable length $(2-3 \mathrm{~mm})$ is found in the Mallard (Anas platyrhynchos; Oliveira et al. 2004). In the much larger domestic turkey, the length of the deferent duct papillae does not seem to exceed $5 \mathrm{~mm}$ (cf. figure in Hess et al. 1976). Even in young (about 3 months old) ratites (Struthioniformes) the length of the deferent duct papillae is shorter than in the Black Coucal with 5-6 mm in the Ostrich and 2-3 $\mathrm{mm}$ in the Rhea (Rautenfeld and Budras 1982). The length of the deferent duct papillae in several fringillid species during the breeding season was found to be $1-1.5 \mathrm{~mm}$ (Bailey 1953), and in the sexually mature Alpine Accentor (Prunella collaris) it was $1.2-1.5 \mathrm{~mm}$ (Chiba and Nakamura 2003).

Thus, typically, deferent duct papillae appear to be short $(<5 \%)$ relative to the distance between the caudal pole of 
the testis and the entry of the deferent ducts into the cloacal wall. In the Black Coucal, however, the total length of the deferent duct papillae comprises about $20 \%$ of that distance. Similarly enlarged papillae have been described for C. medius and C. affinis, two coucal species that also lack a left testis (Bernstein 1860). Behavioural observations suggest that these enlarged papillae may function as a paired secondary copulatory organ ('pseudophalli'): two live male Black Coucals caught immediately after copulation still had their deferent duct papillae everted from the cloaca (A. Wittenzellner, C. Muck and W. Goymann, personal observations). In domestic fowl, the deferent duct papillae are sometimes visible externally during manually induced ejaculation (King 1981, p.133). What kind of selective pressure could have promoted the evolutionary transformation of the deferent duct papillae into copulatory devices? Possibly, an elongated and intromittable right deferent duct papilla is more efficient in transferring sperm than a short phallus vestige, thus partly compensating for the functional loss of one testis and a corresponding lower sperm production rate. From artificial insemination studies in domestic fowl there is evidence that better positioned semen appears to have higher chance of fertilisation (Lake 1981, p. 36). In this context, comparative data from coucal species with two functional testes would be interesting.

Except in one-presumably 1-year-old-individual, the right deferent duct papilla was longer than the left one. This observation confirms similar results of Bernstein (1860) in $C$. affinis and $C$. medius. As the tip of the papillae, owing to their transverse orientation, point to the contra-lateral side (Figs. 1, 4), the larger size of the right papilla might facilitate sperm discharge into a region near the opening of the functional left oviduct within the female cloaca. Interestingly, in some species where males possess an intromittent phallus (Struthionidae, Rheidae, Tinamidae, Anseridae), it matches the asymmetry of the female by bending to the left (King 1981; Oliveira and Mahecha 2000; Delehanty and O’Hearn 2005).

In the macroscopic dissections conducted so far, we could not demonstrate a specific extrinsic musculature of the deferent duct papillae. However, microscopically, the deferent duct papillae of Black Coucals contained circular and longitudinal intrinsic muscle layers around the straight intra-papillary deferent duct portion, peripherally complemented by a loose, cavernous body-like network of connective tissue and smooth muscle fibres. These features suggest an erectility of the long deferent duct papillae. Hess et al. (1976) have reported on a thick circumferential layer of intrinsic smooth musculature adjacent to the epithelial lining of the terminal portion of the deferent duct within the deferent duct papillae of the domestic turkey (M. gallopavo). This might indicate a certain amount of motility of the deferent duct papillae. In addition, Hess et al. (1976) and Lake (1957) deduced from the occurrence of numerous blood sinuses a blood-vascular erectility of the deferent duct papillae in turkeys and fowl. In addition to that, swelling of the deferent duct papillae in other species is assisted by contractions of the deferent duct walls that force sperm into the papillae (Lake 1957). Hence, it is reasonable to assume that the deferent duct papillae in coucals also became erected within the male urodeum during copulation to ensure a guided and accelerated discharge of semen onto the median groove of the phallus, enabling rapid sperm transfer during the typically short copulations of birds without an intromittent phallus (cf. Montgomerie and Doucet 2007).

Starting from this ancestral function, it is possible to conceive an evolutionary pathway ultimately resulting in an intromission of the elongated and erected deferent duct papillae into the female cloaca during copulation and a discharge of sperm from the right papilla directly into the everted opening of the left functional female genital tract. This could be achieved without the need for any evolutionary transformation of the female cloaca (cf. Bernstein 1860). Interestingly, the morphology of the deferent duct papillae resembles that of some extra-cloacal phalloid structures assumed to serve some non-sperm-transfer function in other species, e.g. the pseudophalli in African Buffalo Weavers (Bubalornis; Winterbottom et al. 1999, 2001) and some Australian wrens (Malurus; Mulder and Cockburn 1993; Tuttle and Pruett-Jones 2004; cf. Montgomerie and Briskie 2007). The involvement of phalloid structures incapable of transferring sperm in the copulation process in other species might provide an access to explaining the retention of the left deferent duct papilla in the Black Coucal.

\section{Female}

In contrast to the strongly enlarged deferent duct papillae of the male cloaca, there are no corresponding specialisations of the female cloaca. Likewise, respective topographic positions of left functional ovary and oviduct did not differ from those of other birds (cf. Waibl and Sinowatz 1999). Evolutionary retention of the right testis in males might have occurred to facilitate sperm transfer from the solely sperm-competent right deferent duct papilla to the oppositely positioned cloacal opening of the left oviduct.

As in all bird species investigated so far (Gilbert 1979; Shugart 1988; Birkhead and Møller 1992; Briskie and Montgomerie 1993; Chiba and Nakamura 2001), female Black Coucals possess sperm storage tubules (Fig. 8). They serve to store, keep viable and release spermatozoa in the period between copulation and subsequent fertilisations, i.e. fertilisation may be delayed for a certain period of time.

As a consequence, one insemination may provide spermatozoa for several weeks (Lake 1975; Birkhead et al. 
1989; Birkhead and Fletcher 1993) and, thus, would be sufficient for one clutch to be fertilised. However, frequent copulations may occur for additional reasons, e.g. as a consequence of high sperm competition (Birkhead et al. 1993). Copulation frequency in Black Coucals appears to be high compared to closely related White-browed and Coppery-tailed Coucals (W. Goymann, personal observations). Parker (1998) argues that frequent copulations with little sperm may be more effective than fewer copulations with large amounts of sperm. Alternatively, frequent copulations in Black Coucals may serve social functions rather than the transfer of large amounts of sperm.

In summary, we presented the first detailed morphological description of the peculiar reproductive tract of the African Black Coucal. Our findings do not conform to current theories predicting relatively large testis size in classical polyandrous species, because testis mass and sperm storage sites have been reduced by about one half in Black Coucals. Sperm may be stored in the initial wide loops of the right deferent duct and to some extent in the receptacle of the right deferent duct towards the cloaca. However, both low relative testes mass and the limited sperm reservoir are not indicative of high sperm production rates or intense sperm storage in Black Coucals. Both deferent duct papillae are greatly enlarged and erectile. Only the right deferent duct papilla may function in a more effective transfer of sperm into the cloaca of the female. Future work should look at comparative data in other coucals. Of particular interest would be the White-browed Coucal, which is socially monogamous and lives in much lower densities than the Black Coucal. Hence, sperm competition in this species may be lower than in Black Coucals, but the White-browed Coucal has been described as possessing two functional testes (Friedmann 1927; Rand 1933).

\section{Zusammenfassung}

Nur ein funktionstüchtiger Hoden und lange

Samenleiterpapillen - der eigentümliche

Reproduktionstrakt des Grillkuckucks (Centropus

grillii), ein klassisch polyandrischer Spornkuckuck mit vertauschten Geschlechterrollen

Bei vielen Vögeln ist der männliche Reproduktionstrakt asymmetrisch, wobei der linke Hoden stärker ausgeprägt ist als der rechte. Spornkuckucke (Centropodidae) bilden eine Ausnahme, da bei ihnen der rechte Hoden größer ist als der linke. Dieser Beitrag behandelt die funktionelle Morphologie des Reproduktionstraktes beim Afrikanischen Grillkuckuck, einer Spornkuckucksart mit vertauschten Geschlechterrollen und einem klassisch polyandrischen Paarungssystem. Bei dieser Art ist der linke Hoden zu einem winzigen, scheibenförmigen Rest reduziert, der in den meisten Fällen auch während der Brutzeit makroskopisch nicht sichtbar war. Der reduzierte linke Hoden trägt offenbar nicht zur Produktion von Spermien bei; ein schwach ausgeprägter linker Samenleiter ließ sich makroskopisch sichtbar nachweisen, enthielt jedoch keine Spermien. Im Gegensatz dazu war der rechte Samenleiter (ductus deferens) mit Spermien angefüllt, was auf eine Funktion als Spermienspeicher schließen lässt. Beide Samenleiter münden auf der Spitze außergewöhnlich langer, erektiler Papillen in das Urodaeum der Kloake. Verhaltensbeobachtungen lassen vermuten, dass diese Papillen möglicherweise als „Pseudophalli“ fungieren. Der Hoden macht beim Grillkuckuck nur $0.45 \%$ der Körpermasse aus. Damit ist der Hoden weniger als halb so groß wie die Hoden anderer klassisch polyandrischer Vogelarten. Dies ist ein Paradox, da die Spermienkonkurrenz beim Grillkuckuck relativ hoch sein dürfte. Möglicherweise tragen die durch die alleinige Brutfürsorge von Nesthockern erhöhten energetischen Anforderungen dazu bei, dass beim Grillkuckuck ein Hoden und ein Spermienspeicherorgan eingespart wurden. Die Reduktion der Hodenmasse könnte durch einen häufigen Transfer kleinerer Spermienmengen kompensiert werden. Grillkuckucksweibchen zeigen keine Besonderheiten des Reproduktionstraktes; sie haben jedoch, wie alle anderen Vogelarten, Kanälchen zur Spermienspeicherung.

Acknowledgments We thank the Tanzanian Commission for Science and Technology (COSTECH) and the Tanzania Wildlife Research Institute (TAWIRI) for the permission to conduct this study. Furthermore, we thank Musa Makomba, Christina Muck, Ingrid Schwabl and Andrea Wittenzellner for help with the field work. This work was supported by grant Go985/5-1 from the Deutsche Forschungsgemeinschaft to W.G. Doris Krumnow, technical assistant at the IZW, made and stained the histological sections. Gudrun Wibbelt and Claudia Szentiks, pathologists at the IZW, interpreted the histological sections and assisted in taking the microphotographs. Cornelia Greulich and Beate Peters, librarians of the IZW, and Alexander Krikellis, librarian of the MPI, provided invaluable help in procuring literature sources. This study complies with current laws of Tanzania and Germany.

Open Access This article is distributed under the terms of the Creative Commons Attribution Noncommercial License which permits any noncommercial use, distribution, and reproduction in any medium, provided the original author(s) and source are credited.

\section{References}

Aire TA (2007) Anatomy of the testis and male reproductive tract. In: Jamieson BGM (ed) Reproductive biology and phylogeny of birds. Phylogeny, morphology, hormones, fertilization, vol 6A. Science Publishers, Enfield, pp 37-112 
Andersson M (1995) Evolution of reversed sex roles, sexual size dimorphism, and mating system in coucals (Centropodidae, Aves). Biol J Linn Soc Lond 54:173-181

Bailey RE (1953) Accessory reproductive organs of male Fringillid birds: seasonal variations and response to various sex hormones. Anat Rec 115:1-19

Benoit J (1950) Organes uro-génitaux. In: Grassé PP (ed) Traité de Zoologie, tome 15 (Oiseaux). Masson et Cie, Paris, pp 341-377

Bernstein HA (1860) Über das Vorkommen eines einzigen Hodens bei Centropus medius Muell. und Centropus affinis. Horsf Arch Anat Physiol Wissensch Med 1860:161-168

Birkhead TR, Fletcher FG (1993) Sperm storage and the release of sperm from the sperm storage tubules in Japanese quail (Coturnix japonica). Ibis 136:101-105

Birkhead TR, Møller AP (1992) Numbers and size of sperm storage tubules and the duration of sperm storage in birds: a comparative study. Biol J Linn Soc Lond 45:363-372

Birkhead TR, Hunter FM, Pellatt JE (1989) Sperm competition in zebra finches (Taeniopygia guttata). Anim Behav 38:935-950

Birkhead TR, Briskie JV, Møller AP (1993) Male sperm reserves and copulation frequency in birds. Behav Ecol Sociobiol 32:85-93

Briskie JV, Montgomerie R (1993) Patterns of sperm storage in relation to sperm competition in passerine birds. Condor 95 : $442-454$

Briskie JV, Montgomerie R (2007) Testis size, sperm size and sperm competition. In: Jamieson BGM (ed) Reproductive biology and phylogeny of birds. Phylogeny, morphology, hormones, fertilization, vol 6A. Science Publishers, Enfield, pp 513-551

Calhim S, Birkhead TR (2007) Testes size in birds-quality vs quantity: assumptions, errors and estimates. Behav Ecol 18: 271-275

Chiba A, Nakamura M (2001) Microscopic structure of the sperm storage tubules in the polygynandrous alpine accentor, Prunella collaris (Aves). Acta Zool 82:299-306

Chiba A, Nakamura M (2003) Anatomical and histophysiological characterization of the male cloacal protuberance of the polygynandrous Alpine Accentor Prunella collaris. Ibis 145:E83E93 (online)

Delehanty DJ, O'Hearn PP (2005) Behavioral and morphological asymmetries in chukar Alectoris chukar copulation. J Avian Biol 36:276-279

Friedmann H (1927) Testicular asymmetry and sex ratio in birds. Biol Bull 52:197-207

Gilbert AB (1979) Female genital organs. In: King AS, McLelland J (eds) Form and function in birds, vol 1. Academic, New York, pp 237-360

Goymann W, Wingfield JC (2004) Competing females and caring males. Sex steroids in African black coucals, Centropus grillii. Anim Behav 68:733-740

Goymann W, Wittenzellner A, Wingfield JC (2004a) Competing females and caring males. Polyandry and sex-role reversal in African black coucals, Centropus grillii. Ethology 110:807-823

Goymann W, Moore IT, Scheuerlein A, Hirschenhauser K, Grafen A, Wingfield JC (2004b) Testosterone in tropical birds: effects of environmental and social factors. Am Nat 164:327-334

Goymann W, Kempenaers B, Wingfield JC (2005) Breeding biology, sexually dimorphic development and nestling testosterone concentrations of the classically polyandrous African black coucal, Centropus grillii. J Ornithol 146:314-324

Hess RA, Thurston RJ, Biellier HV (1976) Morphology of the epididymal region and ductus deferens of the turkey (Meleagris gallopavo). J Anat 122:241-252

King AS (1981) Phallus. In: King AS, McLelland J (eds) Form and function in birds, vol 2. Academic, New York, pp 107-147

Kokko H, Jennions MD (2008) Parental investment, sexual selection and sex ratios. J Evol Biol 21:919-948
Lake PE (1957) The male reproductive tract of the fowl. J Anat 91:116-129

Lake PE (1971) The male in reproduction. In: Bell DJ, Freeman BM (eds) Physiology and biochemistry of domestic fowl, vol 7. Academic, New York, pp 1411-1447

Lake PE (1975) Gamete production and the fertile period with particular reference to domesticated birds. Symp Zool Soc Lond $35: 225-244$

Lake PE (1981) Male genital organs. In: King AS, McLelland J (eds) Form and function in birds, vol 2. Academic, New York, pp 1-61

Liebe W (1914) Die männlichen Begattungsorgane der Hausente. Jena Z Med Naturwiss 51:627-696

Ligon JD (1997) A single functional testis as a unique proximate mechanism promoting sex-role reversal in coucals. Auk 114:800-801

Lofts B, Murton RK (1973) Reproduction in birds. In: Farner DS, King JR, Parkes KC (eds) Avian biology, vol 3. Academic, New York, pp 1-107

Møller AP (1988) Testes size, ejaculate quality, and sperm competition in birds. Biol J Linn Soc Lond 33:273-283

Møller AP (1991) Sperm competition, sperm depletion, paternal care, and relative testis size in birds. Am Nat 137:882-906

Montgomerie R, Briskie J (2007) Anatomy and evolution of copulatory structures. In: Jamieson BGM (ed) Reproductive biology and phylogeny of birds. Phylogeny, morphology, hormones, fertilization, vol 6A. Science Publishers, Enfield, pp $115-148$

Montgomerie R, Doucet SM (2007) Courtship and copulation. In: Jamieson BGM (ed) Reproductive biology and phylogeny of birds. Sexual selection, behavior, conservation, embryology, genetics, vol 6B. Science Publishers, Enfield, pp 161-238

Muck C, Kempenaers B, Kuhn S, Valcu M, Goymann W (in press) Paternity in the classical polyandrous African black coucal (Centropus grillii)—a cuckoo accepting cuckoldry? Behav Ecol

Mulder RA, Cockburn A (1993) Sperm competition and the reproductive anatomy of superb fairy-wrens. Auk 110:588-593

NAA (1993) In: Baumel JJ (ed) Handbook of avian anatomy: Nomina anatomica avium, 2nd edn. Harvard University Press, Cambridge, Publications of the Nuttall Ornithological Club No 23, $779 \mathrm{pp}$

Nishiyama H (1950) Studies on the physiology of reproduction in the male fowl. II. On the erection of the rudimentary copulatory organ. Sci Bull Fac Agric Kyushu 12:37-46

Nishiyama H (1951) Studies on the physiology of reproduction in the male fowl. III. On the addition of transparent fluid to the cock's semen. Sci Bull Fac Agric Kyushu 13:377-387

Nishiyama H (1955) Studies on the accessory reproductive organs in the cock. J Fac Agric Kyushu 10:277-305

Oliveira CA, Mahecha GAB (2000) Morphology of the copulatory apparatus of the spotted tinamou Nothura maculosa (Aves: Tinamiformes). Ann Anat 182:161-169

Oliveira CA, Silva RM, Santos MM, Mahecha GAB (2004) Location of the ureteral openings in the cloacas of tinamous, some ratite birds, and crocodilians: a primitive character. J Morphol 260: 234-246

Parker GA (1998) Sperm competition and the evolution of ejaculates: towards a theory base. In: Birkhead TR, Møller AP (eds) Sperm competition and sexual selection. Academic Press, New York, pp 3-54

Parker JE, McKenzie FR, Kempster HL (1942) Fertility in the male domestic fowl. Mo Agric Exp Stn Res Bull 347:1-50

Rand AL (1933) Testicular asymmetry in the Madagascar coucal. Auk 50:219-229

Rautenfeld DBv, Budras K-D (1982) The Bursa cloacae (Fabricii) of struthioniforms in comparison with the bursa of other birds. J Morphol 172:123-138 
Shugart GW (1988) Uterovaginal sperm-storage glands in sixteen species with comments on morphological differences. Auk 105:379-385

Tuttle EM, Pruett-Jones S (2004) Estimates of extreme sperm production: morphological and experimental evidence from reproductively promiscuous fairy-wrens (Malurus). Anim Behav 68:541-550

Vernon CJ (1971) Notes on the biology of the black coucal. Ostrich 42:242-258

Voigt C, Goymann W (2007) Sex-role reversal is reflected in the brain of African black coucals (Centropus grillii). Dev Neurobiol 67:1560-1573

Waibl H, Sinowatz F (1999) Harn- und Geschlechtsapparat. In: Nickel R, Schummer A, Seiferle E (eds) Lehrbuch der Anatomie der Haustiere, vol 5, 3rd edn edn. Anatomie der Vögel. Paul Parey, Berlin, pp 224-264

Wingfield JC, Hegner RE, Dufty AM, Ball GF (1990) The "challenge hypothesis": theoretical implications for patterns of testosterone secretion, mating systems, and breeding strategies. Am Nat 136:829-846

Winterbottom M, Burke T, Birkhead TR (1999) A stimulatory phalloid organ in a weaver bird. Nature 399:28

Winterbottom M, Burke T, Birkhead TR (2001) Thephalloid organ, orgasm and sperm competition in a polygynandrousbird: the redbilled buffalo weaver (Bubalornisniger). Behav Ecol Sociobiol 50:474-482

Witschi E (1935) Seasonal sex characters in birds and their hormonal control. Wilson Bull 47:177-188 